\title{
Treatment and Prognosis of Facial Palsy on Ramsay Hunt Syndrome: Results Based on a Review of the Literature
}

\author{
Rafael da Costa Monsanto ${ }^{1}$ Aline Gomes Bittencourt ${ }^{1,2}$ Natal José Bobato Neto ${ }^{1}$ \\ Silvia Carolina Almeida Beilke ${ }^{1}$ Fabio Tadeu Moura Lorenzetti ${ }^{1,2}$ Raquel Salomone ${ }^{1,2}$ \\ ${ }^{1}$ Department of Otolaryngology, Banco de Olhos de Sorocaba \\ Hospital, Sorocaba, São Paulo, Brazil \\ 2 Department of Otolaryngology, School of Medicine, \\ Universidade de São Paulo, São Paulo, Brazil

\begin{abstract}
Address for correspondence Rafael da Costa Monsanto, MD, Centro de Sorocaba (BOS), Praça Nabek Shiroma, 210, Jardim Emília, Sorocaba/SP, Zip code 18031-060, Brazil
\end{abstract} \\ de Estudos - Departamento de Otorrinolaringologia do Banco de Olhos \\ (e-mail: rafaelmonsanto@hotmail.com).
}

Int Arch Otorhinolaryngol 2016;20:394-400.

\begin{abstract}
Introduction Ramsay Hunt syndrome is the second most common cause of facial palsy. Early and correct treatment should be performed to avoid complications, such as permanent facial nerve dysfunction.

Objective The objective of this study is to review the prognosis of the facial palsy on Ramsay Hunt syndrome, considering the different treatments proposed in the literature.

Data Synthesis We read the abstract of 78 studies; we selected 31 studies and read them in full. We selected 19 studies for appraisal. Among the 882 selected patients, 621 (70.4\%) achieved a House-Brackmann score of I or II; $68 \%$ of the patients treated only with steroids achieved $\mathrm{HB}$ I or II, versus $70.5 \%$ when treated with steroids plus antiviral

\section{Keywords}

- prognosis

- facial palsy

- ramsay hunt syndrome

- varicela zoster

- house-brackmann agents. Among patients with complete facial palsy (grades $\mathrm{V}$ or $\mathrm{VI}$ ), $51.4 \%$ recovered to grades I or II. The rate of complete recovery varied considering the steroid associated with acyclovir: $81.3 \%$ for methylprednisolone, $69.2 \%$ for prednisone; $61.4 \%$ for prednisolone; and $76.3 \%$ for hydrocortisone.

Conclusions Patients with Ramsay-hunt syndrome, when early diagnosed and treated, achieve high rates of complete recovery. The association of steroids and acyclovir is better than steroids used in monotherapy.
\end{abstract}

\section{Introduction}

Ramsay Hunt syndrome (RHS) is an infectious disease caused by the varicella zoster virus (VZV). ${ }^{1}$ The main clinical symptoms are facial palsy, inner ear dysfunction, periauricular pain, and herpetiform vesicles on the pinna. J. Ramsay Hunt, in 1907, was the first author to describe the disease, which now represents the second most common cause of peripheral facial palsy. The incidence of RHS is 5 cases/100,000 people. ${ }^{2}$ It affects mostly patients between the ages of 20 and 30, with no gender predilection. ${ }^{1}$ Spontaneous remission of the facial

received

March 17, 2016

accepted

April 12, 2016

published online

May 30, 2016
DOI http://dx.doi.org/

10.1055/s-0036-1584267. ISSN $1809-9777$. palsy caused by VZV occurs only in a few cases - without proper treatment, only $20 \%$ achieve complete recovery. ${ }^{3}$

The physiopathological mechanism is the reactivation of the VZV in the geniculate ganglion, with subsequent inflammation, edema, and compression of the VII cranial nerve. ${ }^{2}$ Viral demyelination may also contribute to further damage of the nerve. ${ }^{3,4} \mathrm{~A}$ viral prodrome or an upper respiratory tract infection might be the first symptoms, ${ }^{5}$ evolving into severe pain in the pinna, acute facial hypotonia, and a herpetiform vesicular eruption on the pinna, external acoustic meatus, face, tongue, hard palate, neck, larynx, and oral mucosa. ${ }^{2}$
Copyright $\odot 2016$ by Thieme Publicações License terms Ltda, Rio de Janeiro, Brazil

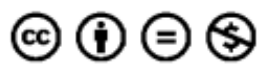


Cochleovestibular impairment such as hypoacusis, tinnitus, and vertigo may occur. The involvement of other cranial nerves, such as V, IX, X, XI, and XII is rare. ${ }^{1,6-8}$ Permanent facial deformity and other possible sequelae of RHS substantially impact patientś social life. Thus, early diagnosis and treatment of this clinical entity is essential to avoid such sequels. $^{6}$

Another clinical presentation of the disease is the "Ramsay Hunt syndrome sine herpete," characterized by peripheral facial paralysis without ear or mouth rash, and the presence of either a 4-fold rise in antibody to VZV or the detection of VZV DNA in skin, blood mononuclear cells, or middle ear fluid. Thus, some patients diagnosed with idiopathic facial palsy could be suffering from zoster sine herpete. ${ }^{9,10}$

The objective of this study was to evaluate the prognosis of facial palsy in RHS after different treatments proposed in the literature, and to determine the best treatment option for these patients.

\section{Materials and Methods}

We performed a systematic review of the literature. The Ethics Committee of the Banco de Olhos de Sorocaba hospital approved this manuscript. We searched the LILACS, SciELO, and PUBMED databases from January to June 2015. The keywords used were: (Ramsay AND hunt) OR ("varicella") AND ("facial paralysis" OR ("facial" AND "paralysis") OR "facial paralysis" OR ("facial nerve" OR ("facial" AND "nerve"). Additional filters used were: period of publication: 1995-2014; human subjects; with abstracts available; Spanish, English, and Portuguese languages. We read the resulting studies in full, and the criteria for study selection were as follows:

\section{a) Inclusion Criteria}

- Case reports and prospective and retrospective studies referring to the prognosis and treatment of facial palsy in RHS.

\section{b) Exclusion Criteria}

- Studies of patients with tumors; traumatic lesions; ear infections; diseases that cause recurrent facial palsy; facial paralysis secondary to intracranial lesions such as cerebrovascular disease.

- Studies that did not classify the facial palsy on the HouseBrackmann (HB) scale.

- Studies of patients with RHS that did not mention the type of treatment, results, or prognosis.

-Fig. 1 shows a flowchart of the decision process regarding the study selection.

\section{Review of the Literature}

\section{Results}

The database search resulted in 259 studies. After reading all the resulting manuscripts in full by two of the authors, we selected 19 studies for appraisal, and included 13 in the quantitative analysis. The studies included a total of 882 patients with facial paralysis caused by $\mathrm{RHS}^{1-8,11-17}$ (-Table 1). The duration of follow-up extended from 73 days to one year among the different studies.

Out of the 882 patients described in these studies, 829 (93.99\%) had facial palsy grades III to VI on the HB scale. Following treatment, 621 out of the 882 (70.4\%) achieved a score of I-II on the HB scale ("good prognosis").

Regarding the HB graduation before treatment, 53 (6\%) were HB II, 150 (17\%) HB III, 289 (32.7\%) HB IV and 390 (44.2\%) HB V or VI. After treatment, 621 (70.4\%) achieved HB I or II and 261 (29.6\%) achieved HB III, IV, or V. All of the patients were treated with steroids ${ }^{1-8,11-17}$; however, Furuta et al $^{7}$ only administered them to patients with facial palsy grades IV-VI at the initial examination. Antiviral agents were used in all patients, in exception of the 47 patients described in Kinishi et al's study. ${ }^{14}$ These authors conducted a clinical trial in which 91 patients were treated with steroids (methylprednisolone, $500 \mathrm{mg}$ on day $1,250 \mathrm{mg}$ on days 2 and 3, and $100 \mathrm{mg} / \mathrm{d}$ for 3 days thereafter), aciclovir ( $4000 \mathrm{mg} / \mathrm{d}$ for 7 days), dextran (500 mL/d for 7 days), vitamins B6 and B12 and peripheral vasodilators; another 43 patients received the same treatment but without the antiviral. Among the patients that received acyclovir, 85 (93.4\%) achieved a good prognosis for facial palsy (HB I or II), compared with only 32 (68\%) of the group that did not receive the antiviral agent $(p<0.05)$. Some authors treated patients with other drugs or therapies, such as dextran (500 $\mathrm{mL}$ for 7 days), ${ }^{6,14}$ peripheral vasodilators, ${ }^{6}$ adenosine triphosphate (ATP), ${ }^{14}$ and vitamins B6 and B12. ${ }^{14}$

The rate of complete recovery regarding the type of steroid associated with acyclovir varied among the studies. $1,4,7,11,14-17$ Regarding the patients treated with prednisone, 290 out of the 419 patients (69.2\%) achieved a good prognosis; among the 192 patients treated with prednisolone, 118 (61.4\%) achieved facial palsy HBI or II, versus 29 out of the 38 (76.3\%) that received hydrocortisone, and 118 of the 145 (81.3\%) patients treated with methylprednisolone. These results are presented in - Table 2.

Some studies ${ }^{6,16}$ compared the facial nerve recovery rate in patients with and without metabolic diseases. Patients with diabetes mellitus achieved worse recovery rates than patients without systemic diseases $(p<0.05)$. Patients older than 60 years with RHS had a delayed recovery of the facial nerve when compared with younger patients $(p<0.05),{ }^{6,14}$ probably due to a less efficient cellular immune system, rather than a reduction in humoral immunity. ${ }^{8}$ Nonetheless, the Uri et $\mathrm{al}^{11}$ study did not evidence differences in the prognosis of facial palsy according to age and gender.

Regarding the prognostic factors, the association between facial palsy and cochleovestibular impairment has worse prognosis than isolated facial nerve palsy $(p=0.029){ }^{11}$ Shim et $\mathrm{al}^{15}$ in a case-control study, observed that the recovery of the facial paralysis was worse when associated with impairment of other cranial nerves, regardless of the initial grade on the HB scale $(p<0.05) .{ }^{15}$

\section{Discussion}

Ramsay Hunt syndrome is responsible for $12 \%$ of cases of facial paralysis, with a worse prognosis than Bell's palsy. ${ }^{11}$ 


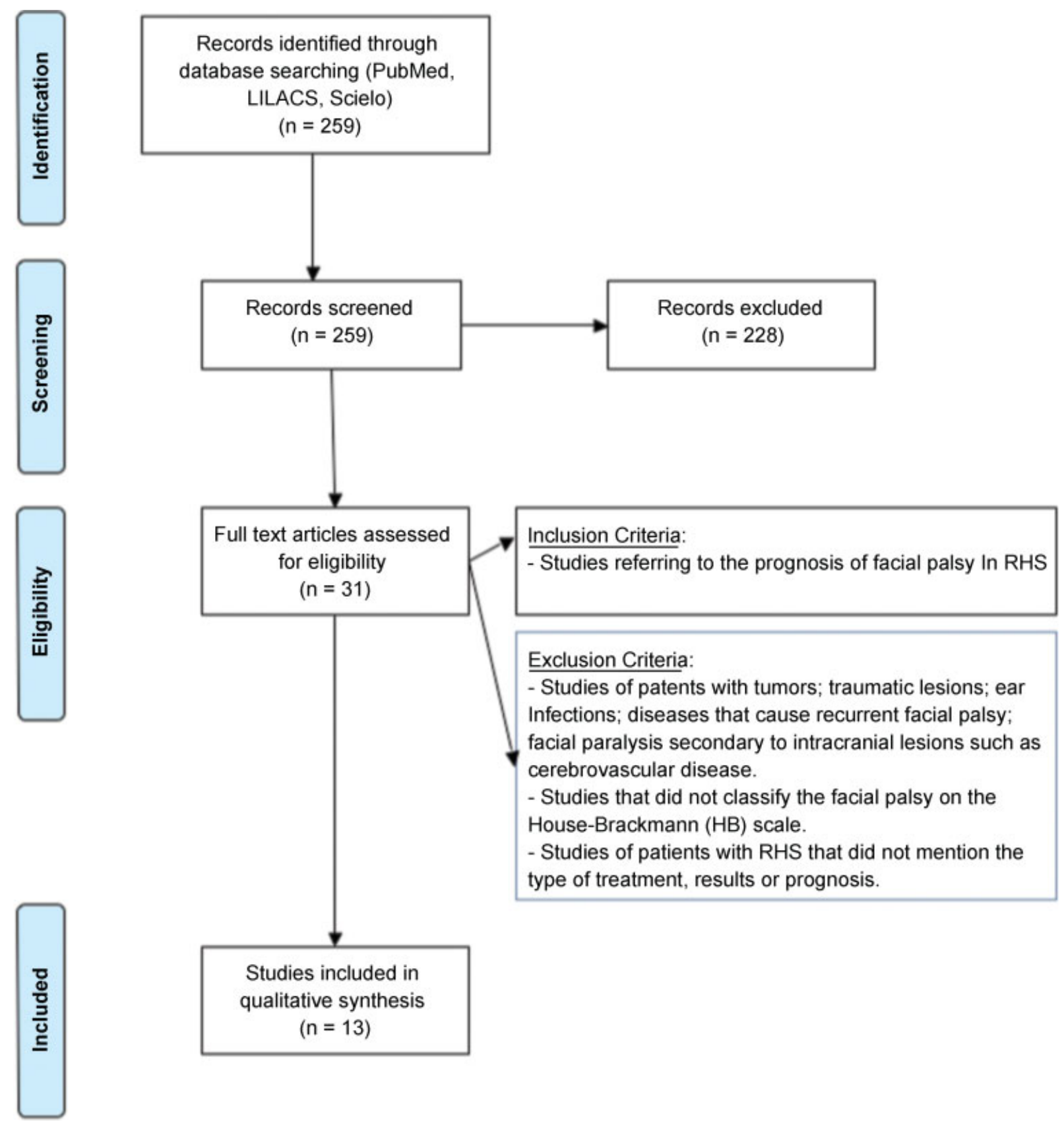

Fig. 1 Flowchart of the decision criteria involved in the selection of the studies.

Other pathologic changes include damage of the Corti organ and Scarpa ganglion, leading to hearing loss and vertigo. ${ }^{4}$

Although previous studies have reported a $10 \%$ recovery rate of patients with complete facial palsy even with correct treatment, ${ }^{11}$ in our study, $51.4 \%$ of patients with facial palsy graded as $\mathrm{HBV}$ to VI treated with steroids plus antiviral agents achieved HB I or II.

Treatment of RHS involves high doses of steroids and virostatic agents, especially acyclovir. The drugs, dosages, and period of treatment used by each author are described in - Table 1. Even though the antiviral agents might theoretically cause several damaging effects, the number of the adverse effects on the selected studies was not significant. ${ }^{3}$
Some authors treated patients with other drugs or therapies, such as dextran (500 mL for 7 days), ${ }^{6,14}$ peripheral vasodilators, ${ }^{6}$ adenosine triphosphate (ATP), ${ }^{14}$ and vitamins B6 and B12. ${ }^{14}$ However, many studies did not report the dosage, time of treatment, or period between the initial symptoms of facial palsy and treatment. Thus, it was difficult to define a treatment protocol and to compare the success of the treatments.

For comparison purposes, "good prognosis" (adequate response to treatment) was considered when the HB grade increased to I or II after treatment. The percentage of patients with a good prognosis varied from $61.1 \%$ to $100 \%$ in the different studies. ${ }^{1,2,4,6,11,16,17}$ In our data, 621 out of the 882 patients (70.4\%) achieved HB I or II. ${ }^{1,2,4,6-8,11-17}$ 
Regarding the different treatment regimens proposed, $68 \%$ of the patients with III to VI on the HB scale achieved a good prognosis when treated with steroids without the antiviral agent, ${ }^{14}$ versus $70.5 \%$ of patients treated with steroids plus antiviral agents. ${ }^{1,2,4,6-8,11-17}$ More specifically, $51.4 \%$ of the patients with facial palsy grade $\mathrm{V}$ and VI completely recovered the facial motor function (HB I or II) ${ }^{1-3,7,8,11-13,15-17}$ when treated with steroids plus antiviral agents.

Table 1 Results regarding the evolution of the facial nerve function obtained by different authors on patients with Ramsay Hunt syndrome, by using different treatments

\begin{tabular}{|c|c|c|c|c|c|c|}
\hline \multirow[t]{2}{*}{ Authors } & \multirow{2}{*}{$\begin{array}{l}\text { No. of } \\
\text { patients }\end{array}$} & \multicolumn{2}{|c|}{ HB scale and patients } & \multirow[t]{2}{*}{ Treatment } & \multirow[t]{2}{*}{ Follow-up } & \multirow{2}{*}{$\begin{array}{l}\text { Patients with } \\
\text { HB I or II AT }\end{array}$} \\
\hline & & BT & AT & & & \\
\hline \multirow[t]{3}{*}{ Ryu et al ${ }^{16}$} & \multirow[t]{3}{*}{155} & HB III - 24 & HB I or II -22 & \multirow{3}{*}{$\begin{array}{l}\text { Prednisolone ( } 80 \mathrm{mg} \text { oral } \\
\text { methylprednisolone per day } \\
\text { for } 4 \text { days, } 60 \mathrm{mg} / \mathrm{d} \text { for } 2 \text { days, } \\
40 \mathrm{mg} / \mathrm{d} \text { for } 2 \text { days, } \\
20 \mathrm{mg} / \mathrm{d} \text { for } 2 \text { days, } \\
\text { and } 10 \mathrm{mg} / \mathrm{d} \text { for } 5 \text { days); } \\
\text { Acyclovir } \\
\text { (4000 } \mathrm{mg} / \mathrm{d} \text { for } 7 \text { days) }\end{array}$} & \multirow[t]{3}{*}{3 months } & \multirow[t]{3}{*}{$91(58.7 \%)$} \\
\hline & & HB IV -53 & HB I or II -35 & & & \\
\hline & & $\mathrm{HB} V$ or $\mathrm{VI}-78$ & HB I or II - 34 & & & \\
\hline \multirow[t]{3}{*}{ Zainine et $\mathrm{al}^{4}$} & \multirow[t]{3}{*}{15} & HB III - 1 & HB I - 1 & \multirow{3}{*}{$\begin{array}{l}\text { Hydrocortisone } \\
\text { (100 mg 3x/day IV for } 8 \text { days) } \\
\text { Acyclovir } \\
\text { (4000 mg/d PO for } 8 \text { days) }\end{array}$} & \multirow[t]{3}{*}{8 months } & \multirow[t]{3}{*}{$10(66.6 \%)$} \\
\hline & & HB IV -8 & $\begin{array}{l}\text { HB I - } 4 \\
\text { HB II - } 2 \\
\text { HB III - } 1 \\
\text { HB IV - } 1\end{array}$ & & & \\
\hline & & $\mathrm{HB} \vee-6$ & $\begin{array}{l}H B I I-3 \\
H B V-3\end{array}$ & & & \\
\hline Kansu et al ${ }^{12}$ & 01 & $\mathrm{HB} \vee-1$ & HB IV - 1 & $\begin{array}{l}\text { Corticosteroid }(1 \mathrm{mg} / \mathrm{kg} / \mathrm{d}) \\
\text { Acyclovir }(90 \mathrm{mg} / \mathrm{kg} / \mathrm{d})\end{array}$ & 4 months & $00(0 \%)$ \\
\hline \multirow[t]{2}{*}{ Donati et $\mathrm{al}^{2}$} & 01 & $\mathrm{HB} \vee-1$ & $\mathrm{HB} I-1$ & $\begin{array}{l}\text { Oral valacyclovir ( } 3 \mathrm{~g} / \text { day, } \\
\text { lowered to } 1.5 \mathrm{~g} / \text { day after } \\
1 \text { week) and } \\
\text { prednisone } 50 \mathrm{mg} / \text { day. } \\
\text { On day } 66-\text { methylpredniso- } \\
\text { lone }(1 \mathrm{~g} / \text { day } 1 . V \text {. for } 5 \text { days. }\end{array}$ & 248 days & $02(100 \%)$ \\
\hline & 01 & $\mathrm{HB} V-1$ & HB I - 1 & $\begin{array}{l}\text { Oral acyclovir ( } 800 \mathrm{mg} / \text { day) for } \\
10 \text { days and } \\
\text { prednisone } 75 \mathrm{mg} / \mathrm{d} \text {. } \\
\text { On day } 37-\text { methylpredniso- } \\
\text { lone, } 1 \mathrm{~g} / \text { day I.V. for } 3 \text { days }\end{array}$ & 73 days & - \\
\hline \multirow[t]{4}{*}{ Shim et al ${ }^{17}$} & \multirow[t]{4}{*}{339} & $\mathrm{HB} \| \mathrm{I}-40$ & $\begin{array}{l}\text { HB I - } 33 \\
\text { HB II - } 7\end{array}$ & \multirow{4}{*}{$\begin{array}{l}\text { Prednisone }(1 \mathrm{mg} / \mathrm{kg} / \mathrm{d} \text { orally } \\
\text { for } 4 \text { days, } \\
\text { tapered to zero until day } 10) \\
\text { Acyclovir } \\
(400 \mathrm{mg} / 8 \mathrm{~h} \text { for } 5 \text { days })\end{array}$} & \multirow[t]{4}{*}{6 months } & \multirow[t]{4}{*}{$225(66.3 \%)$} \\
\hline & & HB III - 95 & $\begin{array}{l}\text { HB I }-52 \\
\text { HB II - 34 } \\
\text { HB III }-9\end{array}$ & & & \\
\hline & & HB IV - 137 & $\begin{array}{l}\text { HB I - 30 } \\
\text { HB II - 52 } \\
\text { HB III - } 26 \\
\text { HB IV }-29\end{array}$ & & & \\
\hline & & $H B V-67$ & $\begin{array}{l}\text { HB I- } 12 \\
\text { HB II }-5 \\
\text { HB III }-21 \\
\text { HB IV }-13 \\
\text { HB V }-16\end{array}$ & & & \\
\hline \multirow[t]{4}{*}{ Kim et $\mathrm{al}^{13}$} & \multirow[t]{4}{*}{11} & $\mathrm{HB} \| \mathrm{I}-5$ & HBI -5 & \multirow{4}{*}{$\begin{array}{l}\text { Steroids ( } 40 \text { to } 60 \mathrm{mg} \text { of } \\
\text { prednisolone, or } 48 \mathrm{mg} \text { of } \\
\text { methylprednisolone, orally, for } \\
10 \text { to } 37 \text { days } \\
\text { Acyclovir ( } 750 \text { to } 4800 \mathrm{mg} \text {, } \\
\text { intravenously, for } 5 \text { to } 12 \text { days) }\end{array}$} & \multirow[t]{4}{*}{6 months } & \multirow[t]{4}{*}{09 (81.8\%) } \\
\hline & & $\mathrm{HB}$ III - 1 & HB II - 1 & & & \\
\hline & & HB IV - 2 & $H B \|-2$ & & & \\
\hline & & $H B \vee-3$ & $\begin{array}{l}\text { HB II - } 1 \\
\text { HB III - } 2\end{array}$ & & & \\
\hline
\end{tabular}


Table 1 (Continued)

\begin{tabular}{|c|c|c|c|c|c|c|}
\hline \multirow[t]{2}{*}{ Authors } & \multirow{2}{*}{$\begin{array}{l}\text { No. of } \\
\text { patients }\end{array}$} & \multicolumn{2}{|c|}{ HB scale and patients } & \multirow[t]{2}{*}{ Treatment } & \multirow[t]{2}{*}{ Follow-up } & \multirow{2}{*}{$\begin{array}{l}\text { Patients with } \\
\text { HB I or II AT }\end{array}$} \\
\hline & & BT & AT & & & \\
\hline \multirow[t]{4}{*}{ Boemo et $\mathrm{al}^{1}$} & \multirow[t]{4}{*}{54} & $\mathrm{HB} \| \mathrm{I}-4$ & $\mathrm{HB} \mathrm{I}-4$ & \multirow{4}{*}{$\begin{array}{l}\text { Acyclovir } 250 \mathrm{mg} / 8 \mathrm{~h} \text { and } \\
\text { methylprednisolone } 120 \mathrm{mg} / \mathrm{d} \\
\text { IV for } 48 \mathrm{~h} \text {; then acyclovir } 850 \\
\text { mg/8h for } 10 \text { days and } \\
\text { methylprednisolone } \\
30 \mathrm{mg} / \mathrm{d} \text { orally, in a decreasing } \\
\text { dosage for } 16 \text { days }\end{array}$} & \multirow[t]{4}{*}{6 months } & \multirow[t]{4}{*}{$33(61.1 \%)$} \\
\hline & & HB III - 8 & $\mathrm{HB} I-8$ & & & \\
\hline & & HB IV - 20 & $\begin{array}{l}\text { HB I - } 10 \\
\text { HB III }-8 \\
\text { HB IV }-2\end{array}$ & & & \\
\hline & & $H B V-22$ & $\begin{array}{l}\text { HB I - } 3 \\
\text { HB II - } \\
\text { HB III - } 6 \\
\text { HB IV - } 5\end{array}$ & & & \\
\hline Gondivkar et al $\left.\right|^{8}$ & 01 & $H B V-1$ & $\mathrm{HBI}-1$ & $\begin{array}{l}\text { Initial dose of acyclovir and } \\
\text { steroids I.V., and a 2-week } \\
\text { course of oral acyclovir and } \\
\text { steroids after discharge; } \\
\text { Transcutaneal electrical nerve } \\
\text { stimulation and facial } \\
\text { neuromuscular exercise. }\end{array}$ & 5 weeks & 01 (100\%) \\
\hline \multirow[t]{3}{*}{ Yeo et al ${ }^{6}$} & \multirow[t]{3}{*}{26} & HB II - 3 & $\begin{array}{l}\mathrm{HB} I-2 \\
\mathrm{HB} \| \mathrm{I}-1\end{array}$ & \multirow{3}{*}{$\begin{array}{l}\text { Prednisolone }(1 \mathrm{mg} / \mathrm{kg} / \mathrm{d} \text { IV for } \\
5 \text { days; then, the dose was } \\
\text { tapered for another } 5 \text { days); } \\
\text { Acyclovir } \\
\text { ( } 5 \mathrm{mg} / \mathrm{kg} / 8 \mathrm{~h} \text { IV for } 5 \text { days); } \\
\text { Famciclovir ( } 500 \text { mg orally for } \\
7 \text { days, after the } 5 \text {-day cycle of } \\
\text { acyclovir); } \\
\text { Dextran; } \\
\text { Peripheral vasodilators. }\end{array}$} & \multirow[t]{3}{*}{6 months } & \multirow[t]{3}{*}{$22(84.6 \%)$} \\
\hline & & HB III - 13 & $\begin{array}{l}\text { HB I - } 7 \\
\text { HB II - } 4 \\
\text { HB III - } 2\end{array}$ & & & \\
\hline & & HB IV -10 & $\begin{array}{l}\text { HB I - } 4 \\
\text { HB II - } \\
\text { HB III - } 1 \\
\text { HB IV - 1 }\end{array}$ & & & \\
\hline \multirow[t]{5}{*}{ Furuta et al ${ }^{7}$} & \multirow[t]{5}{*}{37} & $\mathrm{HB}$ II - 1 & HBI - 1 & \multirow{5}{*}{$\begin{array}{l}\text { Acyclovir ( } 4000 \mathrm{mg} \text { in tablet } \\
\text { form or } 750 \mathrm{mg} \text { per day by } \\
\text { infusion) or valacyclovir } \\
\text { ( } 3000 \mathrm{mg} \text { in tablets) was } \\
\text { administered to all patients for } \\
5 \text { to } 7 \text { days. } \\
\text { Patients with grade IV to VI } \\
\text { facial paralysis were usually } \\
\text { given } 40 \text { to } 60 \text { mg prednisone } \\
\text { for } 4 \text { days. }\end{array}$} & \multirow[t]{5}{*}{6 months } & \multirow[t]{5}{*}{$27(72.9 \%)$} \\
\hline & & HB III - 3 & $\mathrm{HBI}-3$ & & & \\
\hline & & HB IV - 9 & $\mathrm{HB} I-9$ & & & \\
\hline & & $\mathrm{HB} \vee-17$ & $\begin{array}{l}\text { HB I }-9 \\
\text { HB II }-2 \\
\text { HB III }-5 \\
\text { HB IV }-1\end{array}$ & & & \\
\hline & & $\mathrm{HB} \mathrm{VI}-7$ & $\begin{array}{l}\text { HB I - } 2 \\
\text { HB II - 1 } \\
\text { HB III - } 1 \\
\text { HB IV }-3\end{array}$ & & & \\
\hline \multirow[t]{3}{*}{ Uri et al ${ }^{11}$} & \multirow[t]{3}{*}{23} & HB IV - 3 & $\begin{array}{l}\text { HB I - } 2 \\
\text { HB III - } 1\end{array}$ & \multirow{3}{*}{$\begin{array}{l}\text { Acyclovir }(5 \mathrm{mg} / \mathrm{kg} / 8 \mathrm{~h} \\
\text { intravenously for } 7 \text { days) } \\
\text { Hydrocortisone ( } 100 \mathrm{mg} / 8 \mathrm{~h} \\
\text { intravenously for } 7 \text { days) }\end{array}$} & \multirow[t]{3}{*}{1 year } & \multirow[t]{3}{*}{$19(82.6 \%)$} \\
\hline & & $H B V-2$ & $\mathrm{HB} I-2$ & & & \\
\hline & & $\mathrm{HB} \mathrm{VI}-18$ & $\begin{array}{l}\text { HB I - } 11 \\
\text { HB II - } 4 \\
\text { HB III - } 1 \\
\text { HB IV - } 1 \\
\text { HB V - } 1\end{array}$ & & & \\
\hline
\end{tabular}


Table 1 (Continued)

\begin{tabular}{|c|c|c|c|c|c|c|}
\hline \multirow[t]{2}{*}{ Authors } & \multirow{2}{*}{$\begin{array}{l}\text { No. of } \\
\text { patients }\end{array}$} & \multicolumn{2}{|c|}{ HB scale and patients } & \multirow[t]{2}{*}{ Treatment } & \multirow[t]{2}{*}{ Follow-up } & \multirow{2}{*}{$\begin{array}{l}\text { Patients with } \\
\text { HB I or II AT }\end{array}$} \\
\hline & & BT & AT & & & \\
\hline \multirow[t]{8}{*}{ Kinishi et al $^{14}$} & \multirow[t]{4}{*}{91} & HB III - 2 & HBI - 82 & \multirow{4}{*}{$\begin{array}{l}\text { Dextran ( } 500 \mathrm{~mL} \text {, for } 7 \text { days) } \\
\text { Methylprednisolone ( } 500 \mathrm{~m} \text { on } \\
\text { day } 1,250 \mathrm{mg} \text { on days } 2 \text { and } 3 \\
\text { and } 100 \mathrm{mg} \text { for } 4 \text { days } \\
\text { thereafter } \\
\text { Adenosine triphosphate (ATP) } \\
\text { and vitamins B6 and B12 } \\
\text { Acyclovir, } 4000 \mathrm{mg} / \mathrm{d}, 7 \text { days }\end{array}$} & \multirow[t]{8}{*}{6 months } & \multirow[t]{4}{*}{$85(93.4 \%)$} \\
\hline & & HB IV - 17 & HB II - 3 & & & \\
\hline & & $H B V-33$ & HB III - 5 & & & \\
\hline & & $\mathrm{HB} \mathrm{VI}-39$ & HB IV - 1 & & & \\
\hline & \multirow[t]{4}{*}{47} & HB III - 2 & $\mathrm{HB} I-30$ & \multirow{4}{*}{$\begin{array}{l}\text { The same protocol described } \\
\text { above, but without the } \\
\text { acyclovir }\end{array}$} & & \multirow[t]{4}{*}{$32(68 \%)$} \\
\hline & & HB IV - 9 & $H B \|-2$ & & & \\
\hline & & $\mathrm{HB} \vee-17$ & HB III - 10 & & & \\
\hline & & $\mathrm{HB} V \mathrm{VI}-19$ & HB IV - 5 & & & \\
\hline \multirow[t]{4}{*}{ Murakami et al ${ }^{15}$} & \multirow[t]{4}{*}{80} & HB III - 1 & $\mathrm{HB} I-1$ & \multirow{4}{*}{$\begin{array}{l}\text { Prednisone }(1 \mathrm{mg} / \mathrm{kg} / \mathrm{d} \text {, orally } \\
\text { or intravenously for } 5 \text { days; } \\
\text { then, tapered to zero over the } \\
\text { following } 10 \text { days); } \\
\text { Acyclovir }(250 \mathrm{mg} / 8 \mathrm{~h} \text { for } \\
7 \text { days intravenously or } \\
800 \mathrm{mg} 5 \text { times } / \mathrm{d} \text { orally, } \\
\text { for } 7 \text { days) }\end{array}$} & \multirow[t]{4}{*}{1 year } & \multirow[t]{4}{*}{$65(81.25 \%)$} \\
\hline & & HB IV - 21 & $\begin{array}{l}\text { HB I - } 17 \\
\text { HB II }-2 \\
\text { HB III }-2\end{array}$ & & & \\
\hline & & $\mathrm{HBV}-38$ & $\begin{array}{l}\text { HB I - } 20 \\
\text { HB II - } 12 \\
\text { HB III }-5 \\
\text { HB IV }-1\end{array}$ & & & \\
\hline & & $\mathrm{HB} V \mathrm{VI}-20$ & $\begin{array}{l}\text { HB I - 4 } \\
\text { HB II - 9 } \\
\text { HB III - } 7\end{array}$ & & & \\
\hline Total & 882 & - & - & - & - & 621 (70.4\%) \\
\hline
\end{tabular}

Abbreviation: AT, after treatment; BT, before treatment; HB, graduation on the House-Brackmann facial palsy scale.

Kinishi et $\mathrm{al}^{14}$ compared the evolution of patients with facial palsy due to RHS treated with corticosteroids with or without antiviral agents. They demonstrated better evolution of patients treated with methylprednisolone and acyclovir (93.4\% versus $68 \%$ of the patients who did not receive acyclovir) $(p<0.01)$. De Ru et al $^{3}$ demonstrated an oddsratio (OR) for a complete recovery of the facial palsy of 5.5 (95\% confidence interval $[95 \% \mathrm{CI}]=1.6-18.8$ ) with antiviral agents, 2.9 (95\% CI = 1.6-5.4) with steroids in monotherapy, and 8.4 (95\% CI = 3.7-18.9) when both treatments were combined, when compared with no treatment at all. The OR of the combined therapy versus only steroids was 2.8 (95\% $\mathrm{CI}=1.3-5.8)$. Although the studies used different kinds of steroids, dosages, and periods of treatment, the treatment proposed by Kinishi et $\mathrm{al}^{14}$ (methylprednisolone at $500 \mathrm{mg}$ on day $1,250 \mathrm{mg}$ on days 2 and 3, and $100 \mathrm{mg}$ for 4 days

Table 2 Number of patients that achieved a good prognosis of the facial palsy, according to the different classes of steroids associated to acyclovir

\begin{tabular}{|l|l|l|l|l|}
\hline & $\begin{array}{l}\text { No. of patients that } \\
\text { achieved good } \\
\text { prognosis with } \\
\text { Prednisone }\end{array}$ & $\begin{array}{l}\text { No. of patients that } \\
\text { achieved good } \\
\text { prognosis with } \\
\text { Prednisolone }\end{array}$ & $\begin{array}{l}\text { No. of patients that } \\
\text { achieved good } \\
\text { prognosis with } \\
\text { Hydrocortisone }\end{array}$ & $\begin{array}{l}\text { No. of patients that } \\
\text { achieved good } \\
\text { prognosis with } \\
\text { Methylprednisolone }\end{array}$ \\
\hline Ryu et al $^{16}$ & - & $91 / 155$ & - & - \\
\hline Zainine et al & - & - & $10 / 15$ & - \\
\hline Shim et al ${ }^{4}$ & $225 / 339$ & - & - & - \\
\hline Boemo et al & - & - & - & $33 / 54$ \\
\hline Furuta et al & - & $27 / 37$ & - & - \\
\hline Uri et al ${ }^{11}$ & - & - & $19 / 23$ & - \\
\hline Kinishi et al & - & - & - & $85 / 91$ \\
\hline Murakami et al & $-65 / 80$ & - & - & - \\
\hline Total & $290 / 419(69.2 \%)$ & $118 / 192(61.4 \%)$ & $29 / 38(76.3 \%)$ & $118 / 145(81.3 \%)$ \\
\hline
\end{tabular}


thereafter, associated with oral acyclovir, $400 \mathrm{mg} 5 \mathrm{x} / \mathrm{d}$ for 7 days) achieved the higher rate of recovery. Nonetheless, the comparison between the results achieved by the different types of steroids did not achieve statistical significance ( $p>0.05$ ). A study of the molecular mechanisms of corticosteroids conducted by Tsai ${ }^{18}$ showed that methylprednisolone has a higher affinity to glucocorticoid receptors, and a higher anti-inflammatory action when compared with the prednisone, prednisolone, or hydrocortisone; these facts might explain the best results achieved by the authors that used methylprednisolone comparing to other steroids.

Coulson et $\mathrm{al}^{5}$ showed that the group of patients treated with oral prednisone $1 \mathrm{mg} / \mathrm{kg}$ for 14 days, followed by a declining dose of $10 \mathrm{mg} / \mathrm{d}$ down to $0 \mathrm{mg}$, associated with acyclovir $200 \mathrm{mg} 5 \mathrm{x} / \mathrm{d}$ for 21 days 5 days after the onset of the paralysis achieved greater improvement of symptoms than patients treated earlier $(p=0.005)$. A possible explanation for this is that the antiinflammatory action of the steroids should be present at the moment that the inflammation is most intense to achieve the best efficacy. ${ }^{5}$ Nonetheless, a study conducted by De $\mathrm{Ru}^{3}$ demonstrated that best results are achieved when the treatment is initiated on the early onset of the disease. Murakami et al ${ }^{15}$ also showed significant differences in the improvement of facial nerve function depending on the time elapsed between the onset of the symptoms and the start of treatment - the best results are achieved when treatment is introduced before the fifth day of the first symptoms. The same authors indicated that intravenous and oral drugs are equally efficient in terms of the recovery of the function of the facial nerve. They also reported that most of the patients with RHS did not require hospitalization. $^{15}$

Furuta et $\mathrm{al}^{7}$ observed that patients with VZV in the oropharynx or with a viral load above 10,000 copies per 50 $\mu \mathrm{L}$ in the saliva had a worse recovery of the facial nerve function than patients with the isolated cutaneous form of the zoster infection ( $p=0.0019$ ). Thus, the level of VZV DNA in the saliva reflects the kinetics of the viral reactivation in the facial nerve. Other parameters related to worse prognosis were lagophthalmus and dry eye $(p<0.05)$, which indicates the involvement of the large superficial petrosal nerve. ${ }^{5}$

None of the selected studies refer to surgical management of the facial palsy in Ramsay Hunt syndrome. Bodénez et al, ${ }^{19}$ however, proposed a flowchart regarding to the surgical approach - if the patient maintains complete facial palsy (HB V or VI) after the clinical treatment, the electromyography shows axonal loss higher than $95 \%$ and a time elapsed since the beginning of the facial palsy of 15 days, a surgical approach may be indicated.

\section{Final Comments}

Overall, patients with Ramsay Hunt syndrome achieved a high rate of complete recovery of the facial nerve function (70.4\%) after the different proposed treatments. The combination of steroids and acyclovir reached better recovery rates than steroids in monotherapy. Dosage and period of treatment greatly varied among studies.
Clinical data such as age, associated metabolic diseases, impairment of the cochleovestibular, or other cranial nerves, oropharynx lesions, dry eye, and lagophthalmus must be assessed at the initial physical examination, since they suggest worse prognosis of the facial palsy secondary to Ramsay Hunt syndrome.

\section{References}

1 Boemo RL, Navarrete ML, García-Arumí AM, Copa SL, Graterol D, Scherdel EP. Ramsay Hunt syndrome: our experience. Acta Otorrinolaringol Esp 2010;61(6):418-421

2 Donati D, De Santi L, Ginanneschi F, Cerase A, Annunziata P. Successful response of non-recovering Ramsay Hunt syndrome to intravenous high dose methylprednisolone. J Neurol Sci 2012; 318(1-2):160-162

3 de Ru JA, van Benthem PPG. Combination therapy is preferable for patients with Ramsay Hunt syndrome. Otol Neurotol 2011;32(5): 852-855

4 Zainine R, Sellami M, Charfeddine A, Beltaief N, Sahtout S, Besbes G. Ramsay Hunt syndrome. Eur Ann Otorhinolaryngol Head Neck Dis. Head and Neck Dis 2012;129:22-25

5 Coulson S, Croxson GR, Adams R, Oey V. Prognostic factors in herpes zoster oticus (ramsay hunt syndrome). Otol Neurotol 2011; 32(6):1025-1030

6 Yeo SW, Lee DH, Jun BC, Chang KH, Park YS. Analysis of prognostic factors in Bell's palsy and Ramsay Hunt syndrome. Auris Nasus Larynx 2007;34(2):159-164

7 Furuta Y, Aizawa H, Ohtani F, Sawa H, Fukuda S. Varicella-zoster virus DNA level and facial paralysis in Ramsay Hunt syndrome. Ann Otol Rhinol Laryngol 2004;113(9):700-705

8 Gondivkar S, Parikh V, Parikh R. Herpes zoster oticus: A rare clinical entity. Contemp Clin Dent 2010;1(2):127-129

9 Sweeney CJ, Gilden DH. Ramsay Hunt syndrome. J Neurol Neurosurg Psychiatry 2001;71(2):149-154

10 Gilchrist JM. Seventh cranial neuropathy. Semin Neurol 2009; 29(1):5-13 10.1055/s-0028-1124018

11 Uri N, Greenberg E, Kitzes-Cohen R, Doweck I. Acyclovir in the treatment of Ramsay Hunt syndrome. Otolaryngol Head Neck Surg 2003;129(4):379-381

12 Kansu L, Yilmaz I. Herpes zoster oticus (Ramsay Hunt syndrome) in children: case report and literature review. Int J Pediatr Otorhinolaryngol 2012;76(6):772-776

13 Kim YH, Chang MY, Jung HH, et al. Prognosis of Ramsay Hunt syndrome presenting as cranial polyneuropathy. Laryngoscope 2010;120(11):2270-2276

14 Kinishi M, Amatsu M, Mohri M, Saito M, Hasegawa T, Hasegawa S. Acyclovir improves recovery rate of facial nerve palsy in Ramsay Hunt syndrome. Auris Nasus Larynx 2001;28(3):223-226

15 Murakami S, Hato N, Horiuchi J, Honda N, Gyo K, Yanagihara N. Treatment of Ramsay Hunt syndrome with acyclovir-prednisone: significance of early diagnosis and treatment. Ann Neurol 1997; 41(3):353-357

16 Ryu EW, Lee HY, Lee SY, Park MS, Yeo SG. Clinical manifestations and prognosis of patients with Ramsay Hunt syndrome. Am J Otolaryngol 2012;33(3):313-318

17 Shim HJ, Jung H, Park DC, Lee JH, Yeo SG. Ramsay Hunt syndrome with multicranial nerve involvement. Acta Otolaryngol 2011; 131(2):210-215

18 Tsai MJ, O'Malley BW. Molecular mechanisms of action of steroid/ thyroid receptor superfamily members. Annu Rev Biochem 1994; 63:451-486

19 Bodénez C, Bernat I, Willer JC, Barré P, Lamas G, Tankéré F. Facial nerve decompression for idiopathic Bell's palsy: report of 13 cases and literature review. J Laryngol Otol 2010;124(3):272-278 